\title{
PERFORMANCE OF GINGER CROP UNDER DIFFERENT IRRIGATION DEPTHS
}

\author{
EFEITOS DE DIFERENTES LÂMINAS DE IRRIGAÇÃO NA CULTURA DO \\ GENGIBRE
}

\section{Caroline Merlo MENEGHELLI ${ }^{1}$; Marcelo Rodrigo KRAUSE ${ }^{1}$; Juniomar SCHMIDT ${ }^{2}$; João Nacir COLOMBO ${ }^{2}$; Gustavo Haddad Souza VIEIRA ${ }^{2}$}

1. Universidade Federal de Viçosa, Viçosa, MG, Brasil. caroline.meneghelli@ufv.br. 2. Instituto Federal de Educação, Ciência e Tecnologia do Espírito Santo, Campus de Santa Teresa, Santa Teresa, ES, Brasil.

\begin{abstract}
In order to achieve good yields and profitability from ginger crops, the water supply must be adequate. However, there are few studies available which have evaluated the adequate water supply to this vegetable. The objective of this study was to evaluate the effect of different irrigation depths on the development and productivity of ginger plants. The research was conducted at the "Sítio Schmidt" farm located in the municipality of Santa Maria de Jetibá, in the central mountainous region of Espírito Santo State, Brazil. The experimental design was a randomized block design with four replications, each experimental unit consisting of three rows at a spacing of $0.90 \mathrm{~m}$ and $0.10 \mathrm{~m}$ between plants of two meters extension, totaling 20 experimental units. The treatments consisted of application of five irrigation depths equivalent to: $50 \%, 75 \%$, $100 \%, 125 \%$ and $150 \%$ of crop evapotranspiration (ETc). We evaluated the number of sprouts; average mass of export quality rhizome; the production of export, small and total rhizomes $\left(\mathrm{t} \mathrm{ha}^{-1}\right)$; and water use efficiency. The total water depth applied in the range 1100-1200 mm per cycle favors the development of ginger plants, providing the highest yields of total and export rhizomes, the greatest average mass of export quality rhizome and lowest production of small rhizomes.
\end{abstract}

KEYWORDS: Water use. Efficiency. Evapotranspiration. Horticulture. Water stress.

\section{INTRODUCTION}

Ginger (Zingiber officinale Roscoe) belongs to the Zingiberaceae family (RAVINDRAN; NIRMALBABU; SHIVA, 2005), and is notable for its medicinal and aromatic properties, and its importance as a spice in many parts of the world (ZAMBRANO-BLANCO, 2015). Information on its origin and domestication reveal that the various species of the Zingiber genus are native to Southeast Asia and, from there, have spread throughout the tropical and subtropical regions of the world (KIZHAKKAYIL; SASIKUMAR, 2011).

The cultivation of ginger was introduced in Brazil soon after the beginning of European colonization. However, only in the last decades, after introduction of giant rhizome varieties by Japanese farmers, has it become a commercial crop in some states of the southeastern and southern regions of Brazil (ELPO; NEGRELLE; RÜCKER, 2008). In Espírito Santo State, ginger was introduced on a commercial scale a little more than 10 years ago as an alternative source of income for family-based producers, and from then on the state came to occupy a prominent position in the national scenario (ESPÍNDULA JÚNIOR et al., 2014). Currently, Espírito Santo stands out as the largest producer and exporter of ginger, contributing to $60 \%$ of national production and $80 \%$ of exports.

In order to achieve good productivity and profitability with ginger crops, intrinsic factors, cultural practices, sanitation, irrigation and nutrition must be at adequate levels. Among these factors, water is one that is most influential on the growth and development characteristics of plants (ALVARENGA, 2004). KUMAR et al. (2018) reported that ginger crops demand a large amount of water, requiring continuous irrigation throughout the cycle ( 8 to 9 months). Thus, irrigation is a viable technique for substantial improvement in productivity (PACHECO et al., 2016).

It is apparent that published information on the effect of irrigation on ginger crops, as well as on the variation of plant responses to different applied depths, is still scarce in Brazil. Thus, studies are needed that seek to maximize productivity combined with efficient water use.

In view of the above, the objective of this study was to evaluate the effect of different 
irrigation depths on the vegetative development and productivity of ginger crops.

\section{MATERIAL AND METHODS}

The research was conducted at the "Sítio Schmidt" farm located in the municipality of Santa Maria de Jetibá, in the central mountainous region of Espírito Santo State, Brazil (geographical coordinates $19^{\circ} 48^{\prime} 21^{\prime \prime} \mathrm{S}, 40^{\circ} 40^{\prime} 44^{\prime \prime} \mathrm{W}$, altitude $910 \mathrm{~m}$ ), from September 2014 to September 2015. Average annual temperature was $25.3{ }^{\circ} \mathrm{C}$ and average precipitation was $1078 \mathrm{~mm}$. According to the Köppen classification, the climate of the region is $\mathrm{Cwb}$ type, characterized as tropical climate of altitude. The topography is flat with a slightly sloping and the soil is clayey texture.

Soil preparation consisted of plowing and harrowing. Grooves of $0.20 \mathrm{~m}$ depth were opened, and the seedlings distributed longitudinally and then covered with $0.10 \mathrm{~m}$ of soil. Selected rhizomes, which had 3 to 6 sprouts, with a mean mass of $90 \mathrm{~g}$ were used for planting. The spacing used for planting was $0.9 \times 0.1 \mathrm{~m}$. The planting and cover fertilization was carried out according to Prezotti et al. (2007).

We used a randomized block design (RBD) with four replications, each experimental unit consisting of three rows spaced at $0.90 \mathrm{~m}$, with 0.10 $\mathrm{m}$ between plants. The length of each row was two linear meters, and the central row was considered useful. The treatments consisted of the application of five irrigation depths, being equivalent to: $50 \%$, $75 \%, 100 \%, 125 \%$ and $150 \%$ of the crop evapotranspiration (ETc), totaling 20 experimental units.

During the harvest cycle (300 days), cultivation practices such as weeding and ridging were carried out. The initial weeding was performed 40 days after planting (DAP) and the other weeding occurred during the ridgings, at 60 and 130 DAP.

Irrigation was controlled using Irriplus ${ }^{\circledR}$ software (MANTOVANI; BERNARDO; PALARETTI, 2009), by which the ginger water demand was determined, using adjustment coefficients applied to the reference evapotranspiration (ETo), calculated by the Penman-Monteith method (ALLEN et al., 1998). The gross depth was calculated using the water balance, where the inputs of water were the irrigation and effective rainfall and the outputs were crop evapotranspiration (ETc) and percolation, besides the depth considered for the root system. To estimate crop evapotranspiration, the following equation, proposed by Doorenbos and Pruitt (1977) and modified by Mantovani and Costa (1998), was used:

$$
E T c=E T_{o} K_{C} K_{S} K_{L}
$$

where $E T_{c}=$ crop evapotranspiration $\left(\mathrm{mm} \mathrm{d}^{-1}\right), E T o$ $=$ reference evapotranspiration $\left(\mathrm{mm} \mathrm{d}^{-1}\right), K_{C}=\mathrm{crop}$ coefficient, $K_{S}=$ water stress coefficient, and $K_{L}=$ localization coefficient.

The Kc values used were $0.4 ; 1.15$ and 0.8 for phases 1; 3 and final (in phases 2 and 4 the $\mathrm{Kc}$ was increasing and decreasing, respectively) and the duration of the development stages was 45; 105; 90 and 60 days, respectively for phases 1, 2, 3 and 4 . $\mathrm{Ks}$ values were calculated by the logarithmic method (MANTOVANI; BERNARDO; PALARETTI, 2009).

We used micro sprays (RBS Plastics brand), with a flow rate of $18.1 \mathrm{~L} \mathrm{~h}^{-1}$ operating at $100 \mathrm{kPa}$ pressure with a application intensity of $40.22 \mathrm{~mm} \mathrm{~h}^{-}$ 1. After evaluation, the equipment showed an efficiency of $92 \%$ (Christiansen Uniformity Coefficient). For variation of the applied depth between the treatments, different numbers of emitters per plant were used. Thus, the spacing between emitters was 1 meter ( $50 \%$ treatment); 0.66 m ( $75 \%$ treatment); $0.50 \mathrm{~m}$ ( $100 \%$ treatment $) ; 0.40$ $\mathrm{m}(125 \%$ treatment); and $0.33 \mathrm{~m}$ ( $150 \%$ treatment). The irrigation frequency was not fixed, because the scheduling was done based on the soil moisture of the $100 \%$ treatment.

During the vegetative development, at 35 DAP, the number of sprouts on each rhizome was evaluated by counting the number of emerged stems. Seven months after planting, when we observed a reduction in plant size, yellowing of leaves and withering sprouts, the crop was harvested using a hoe. The plants were removed and the rhizomes washed and classified as either export quality (rhizomes with mass above $150 \mathrm{~g}$ ) or small (rhizomes with mass below $150 \mathrm{~g}$ ). The rhizomes were weighed and then the production of export rhizomes, yield of small rhizomes and yield of total rhizomes were calculated, the latter value being the sum of export quality and small rhizomes. In addition, water use efficiency was calculated, based on the relation between total productivity of rhizomes and total applied depth.

All the evaluated variables were submitted to tests of normality (Lilliefors) and homocedasticity (Bartlet), assumptions for performing analysis of variance. Data on the variable number of sprouts initially did not meet the assumptions, and were log-transformed and submitted again to the validation tests. In order to 
compare the treatments, their degrees of freedom were decomposed into regression models using the orthogonal polynomials method. All statistical analyses were carried out using Assistat version 7.7 software (SILVA; AZEVEDO, 2016) and Sisvar version 5.6 software (FERREIRA, 2011).

\section{RESULTS AND DISCUSSION}

Figure 1 shows the water balance, representing the irrigation management, the critical limits of soil water storage (field capacity and permanent wilting point), the effective precipitation and the soil moisture for each of the treatments during the experimental period (September 2014 to September 2015).

It was observed that the highest precipitation frequency occurred in the months November and December 2014, providing that the soil, in all treatments, remained above the safety humidity. Thus, there was 'no difference between the soil moisture content between the treatments during this stage. This soil moisture is essential during the budding period of the rhizome sprouts, and the lack or excess of water in the soil may hinder sprouting, depending on the duration of water stress (MANHÃES et al., 2015).

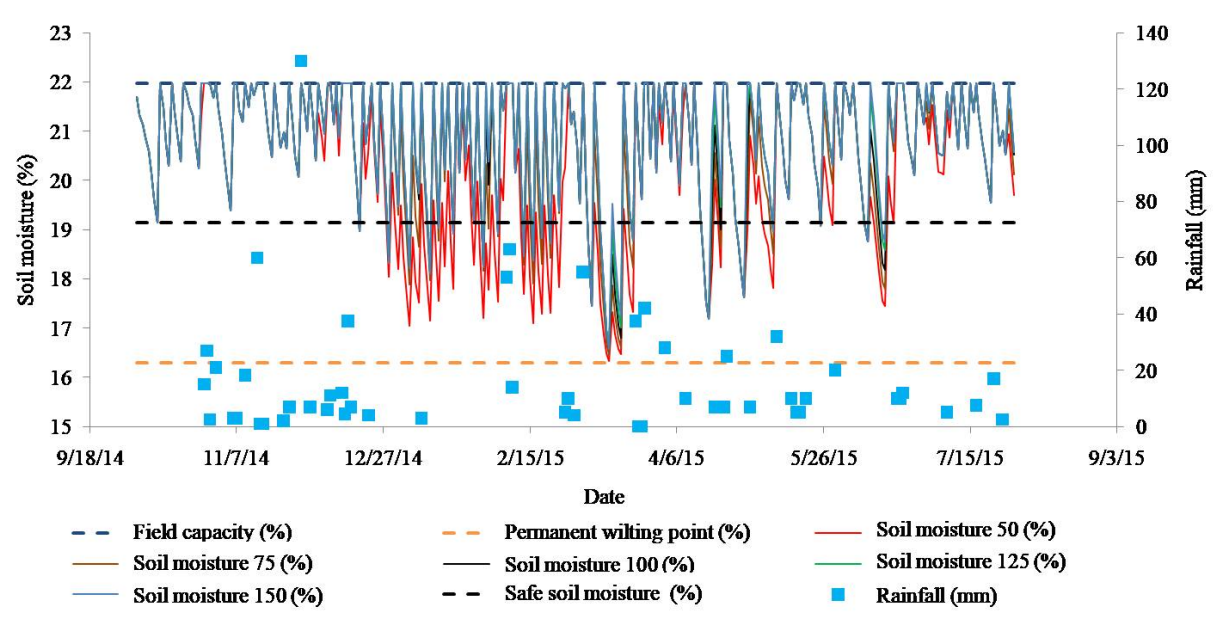

Figure 1. Water balance representing the irrigation management, the critical limits of soil water storage (field capacity and permanent wilting point), the effective rainfall and the soil moisture for each of the treatments during the experimental period (September 2014 to September 2015).

Significant differences in soil moisture during the experimental period were observed between the $50 \%$ and $150 \%$ treatments, where the $150 \%$ treatment remained, most of the time, in the appropriate moisture range. Regarding the 50\% treatment, it is observed that there was a decrease in soil moisture in most of the crop cycle, reaching near the permanent wilting point. Regarding the treatments $75 \%, 100 \%$ and $125 \%$, no significant differences were observed between them. In addition, the lowest soil moisture observed in all treatments during the months of January and February may be related to the lowest precipitation frequency.

The software used in the present study considers that any applied water that exceeds the storable water is considered excess, i.e. it is not retained by the soil and is percolated to layers below the effective root zone. For this reason, when applying depths referring to the treatments of 125 and $150 \%$ of ETc, the graph shows the maximum soil moisture equal to the field capacity.
Figure 2 shows the meteorological variables of relative air humidity $(\%)$, solar radiation $\left(\mathrm{MJ} \mathrm{m}^{-2}\right.$ day $\left.^{-1}\right)$, rainfall $(\mathrm{mm})$ and wind speed $\left(\mathrm{m} \mathrm{s}^{-1}\right)$ during the experimental period. Relative air humidity and solar radiation during the experiment ranged from $64.79 \%$ to $100 \%$ and from 3.53 to $31.97 \mathrm{MJ} \mathrm{m}^{-2}$ day ${ }^{1}$, respectively.

Figure 3 shows that in the period between October 2014 (planting) and March 2015, the highest average temperature $\left(20.89{ }^{\circ} \mathrm{C}\right)$ and variation of the thermal amplitude $\left(9.01{ }^{\circ} \mathrm{C}\right)$ was recorded compared to April, when there was a reduction in the mean temperature $\left(17.93{ }^{\circ} \mathrm{C}\right)$ and thermal amplitude $\left(6.23{ }^{\circ} \mathrm{C}\right)$. In this sense, it was observed that average temperatures which occurred until the month of March favored the development of ginger. Carmo and Balbino (2015) point out that the ginger plant is adapted to average temperatures above $21{ }^{\circ} \mathrm{C}$; in the present study, the temperature during most of the crop development stage remained close to this value. 


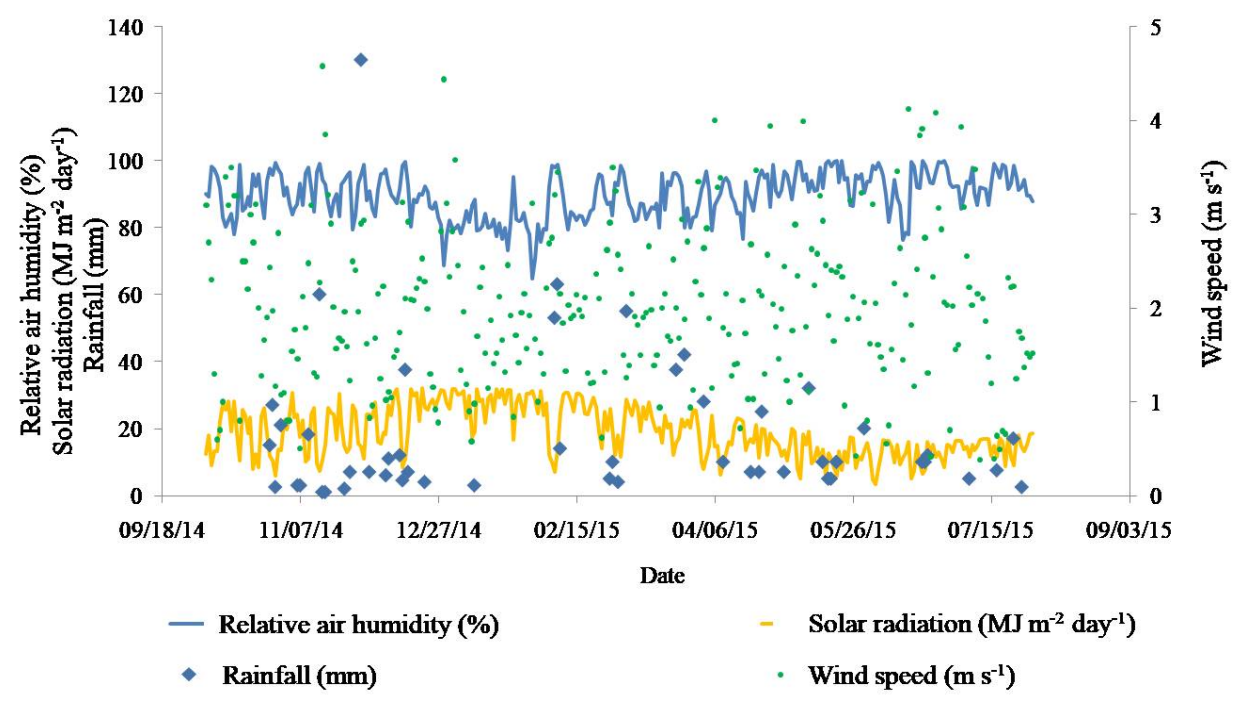

Figure 2. Relative air humidity, solar radiation, rainfall and wind speed during the experimental period (September 2014 to September 2015).

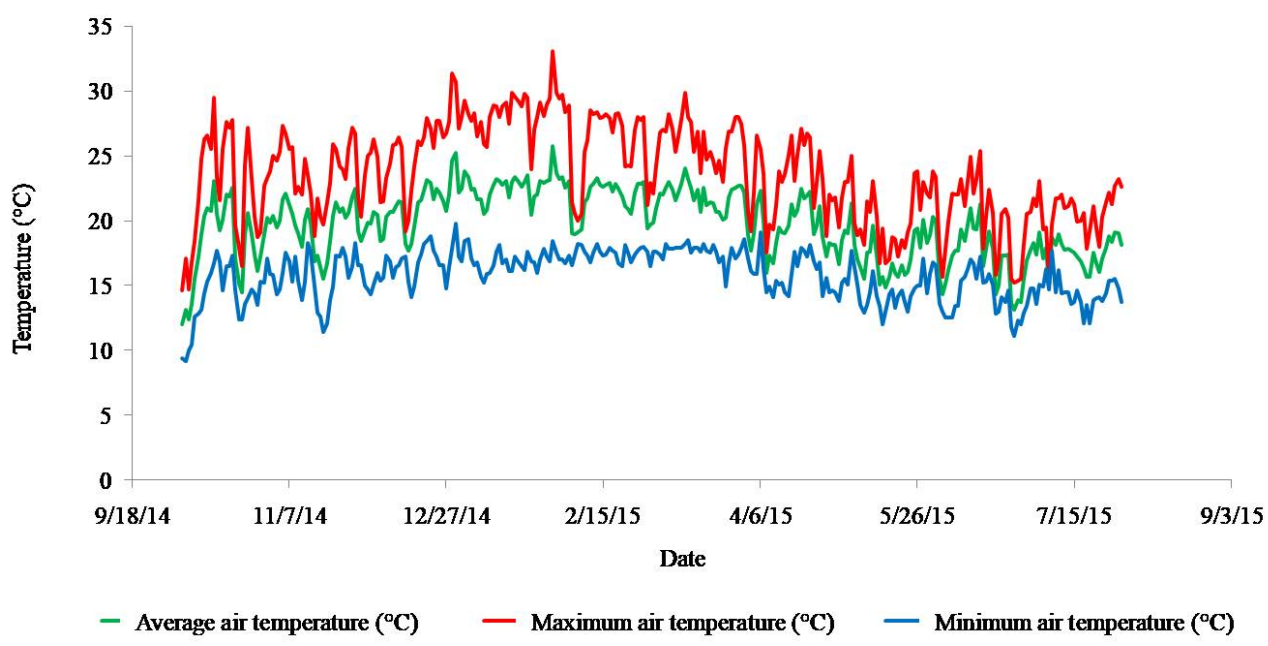

Figure 3. Average, maximum and minimum air temperature during the experimental period (September 2014 to September 2015).

With the increase in the volume of water applied, there was an increase in the values of the analyzed variables (Table 1). In the treatment where the $50 \%$ ETc depth was applied, the plants received a smaller volume of water (total depth and irrigation) than the others treatments during the crop cycle. On the other hand, with the same treatment, the excesses related to irrigation and total water (irrigation + rainfall) were lower, demonstrating less waste of water when compared to the other treatments.

Figure 4 shows the sprouts per plant (a), the average mass of export quality rhizome (b), the water use efficiency (c), the total rhizomes productivity (d), the export rhizomes productivity (e) and small rhizomes productivity (f) of ginger due to different irrigation depths. The number of sprouts per plant and water use efficiency both showed linear behavior, whereas the average mass of export quality rhizome, total rhizome productivity, export rhizomes productivity and small rhizomes productivity all presented quadratic behavior.

With regard to the number of sprouts, as the irrigation depths were increased, there was a reduction in sprout emission. The highest number of sprouts per ginger plant was observed at the applied depth of $919.68 \mathrm{~mm}$ (7.42 sprouts per plant) $(\mathrm{P}=$ 0.032 ). The applied depth of $1,231.67 \mathrm{~mm}$ probably provided a soil moisture content that created a favorable environment for nutrient absorption, resulting in the highest number of sprouts per plant (ISLAM; RAHIM; IQBAL, 2015). With respect to the $919.68 \mathrm{~mm}$ depth, which corresponds to only $50 \%$ of the crop ETc, the lowest sprout emission per 
plant was expected since this treatment provided a smaller amount of water for the crop compared to the other treatments. It is considered that the highest precipitation frequency observed in the months from November to December 2014 (Figure 2), which coincides with ginger sprouting, led all treatments to remain above the security soil moisture and thus, the depth of $919.68 \mathrm{~mm}$ showed greater values of sprouts than the other treatments.

Table 1. Irrigation, rainfall and total excesses, ETc, irrigation, total and effective rainfall, and total water depth in the crop cycle for each treatment.

\begin{tabular}{ccccccccc}
\hline $\begin{array}{c}\text { Treatment } \\
(\mathrm{ETc})\end{array}$ & $\begin{array}{c}\text { Irrigation } \\
\text { excess } \\
(\mathrm{mm})\end{array}$ & $\begin{array}{c}\text { Rainfall } \\
\text { excess } \\
(\mathrm{mm})\end{array}$ & $\begin{array}{c}\text { Total } \\
\text { excess } \\
(\mathrm{mm})\end{array}$ & $\begin{array}{c}\text { ETc } \\
(\mathrm{mm})\end{array}$ & $\begin{array}{c}\text { Irrigation } \\
(\mathrm{mm})\end{array}$ & $\begin{array}{c}\text { Rainfall } \\
(\mathrm{mm})\end{array}$ & $\begin{array}{c}\text { Effective } \\
\text { rainfall } \\
(\mathrm{mm})\end{array}$ & $\begin{array}{c}\text { Total } \\
\text { water } \\
\text { depth } \\
(\mathrm{mm})\end{array}$ \\
\hline $50 \%$ & 10.54 & 312.24 & 322.78 & 414.87 & 336.3 & 896.2 & 583.38 & 919.68 \\
$75 \%$ & 66.31 & 331.9 & 398.21 & 462.53 & 504.66 & 896.2 & 564.25 & $1,068.91$ \\
$100 \%$ & 230.11 & 337.32 & 567.43 & 476.29 & 672.79 & 896.2 & 558.88 & $1,231.67$ \\
$125 \%$ & 371.58 & 338.92 & 710.5 & 479.12 & 841.02 & 896.2 & 557.28 & $1,398.3$ \\
$150 \%$ & 514.54 & 340.55 & 855.09 & 480.61 & $1,009.28$ & 896.2 & 555.65 & $1,564.93$ \\
\hline
\end{tabular}
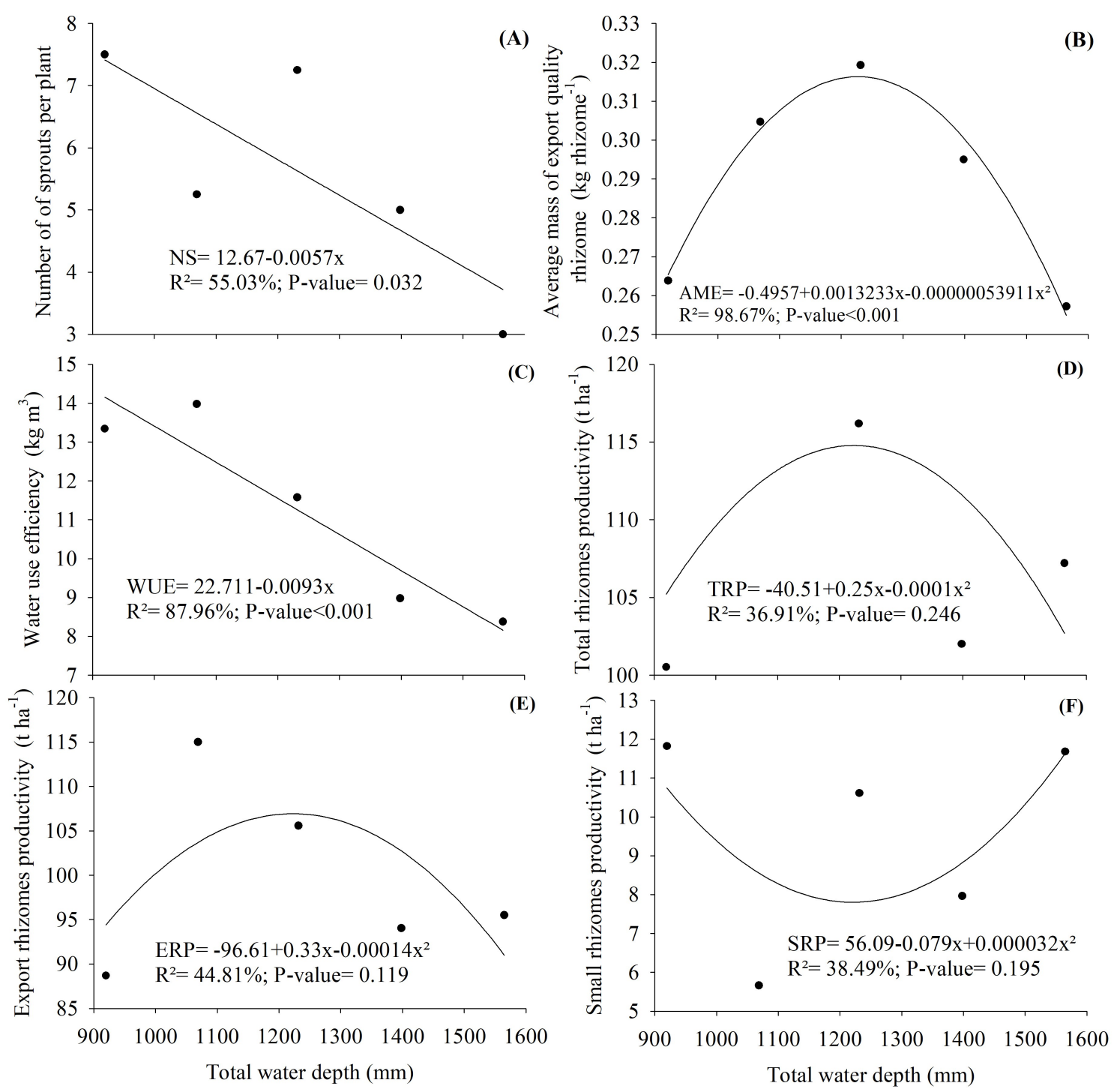

Figure 4. Number of sprouts per plant (A), average mass of export quality rhizome (B), water use efficiency (C), total rhizomes productivity (D), export rhizomes productivity (E) and small rhizomes productivity $(\mathrm{F})$ of ginger due to different irrigation depths. 
On the other hand, the lowest numbers of sprouts per plant (3.74) occurred with the depth of $1,564.93 \mathrm{~mm}$. It is worth mentioning that the irrigation depths were based on the crop ETc, with the depth of $1,564.93 \mathrm{~mm}$ being equivalent to $150 \%$ of the ETc. Consequently, the 1,564.93 $\mathrm{mm}$ depth treatment probably subjected the crop rhizomes to waterlogged conditions for some hours after the irrigation, resulting in limited soil aeration which may have caused problems with sprouting. This stress may have been one of the factors involved in the lowest number of sprouts per plant.

Brazilian ginger is generally marketed in the "in natura" form and is mainly intended for export. The rhizomes destined for export are generally larger, with better appearance, and therefore of the highest added value. Thus, the average mass of the export quality rhizomes is an important variable, since it is one of the characteristics that determine the classification of the rhizome as export quality.

The highest value reported for the average mass of export quality rhizomes was $0.316 \mathrm{~kg}$ per rhizome, obtained with the application of $1,227.30$ $\mathrm{mm}$ depth, which approximates to $100 \%$ ETc ( $\mathrm{P}=$ $0.000)$. Water is one of the main factors in production, being responsible for plant growth and development. In the present study, the soil water content was 'similar that of the soil producing rhizomes for export, reported by Gava at al. (2016).

With regard to the lowest average mass of export ginger rhizomes, this was obtained with the application of $1,564.93 \mathrm{~mm}$ depth, followed by $919.68 \mathrm{~mm}$ depth, producing mean values of 0.255 $\mathrm{kg}$ and $0.266 \mathrm{~kg}$ per rhizome, respectively. The applied depth of 1,564.93 $\mathrm{mm}$ probably exceeded the amount of water required by the crop, causing soil swamping and interference with rhizome development. According to Costa et al. (2017), the highest irrigation levels (125 and $150 \%$ of ETc) subject the plants to $\mathrm{O}_{2}$ deficiency (hypoxia) in the edaphic environment due to the excess water accumulating in the soil. Dutra et al. (2012) stated that soaked soil results in a lack of oxygen supplied to the roots, which causes the root tissues to die because conditions favor lactic fermentation and acidosis in the cells, and can also lead to a reduction in nutrient and water absorption due to lack of energy.

On the other hand, the applied depth of $919.68 \mathrm{~mm}$ probably subjected the plants to water deficiency. A marked response of plants subjected to water deficiency is reduced turgescence of the cells and, with progressive dehydration of the protoplasm, there is an increase in the concentration of the cellular content, leading to decreased water potential, which can compromise all vital processes responsible for plant growth (TAIZ; ZEIGER, 2013). In addition, the stress promoted by water deficit can lead to loss of plant biomass (RODRIGUES et al., 2016), explaining the lowest average mass of export quality rhizomes with this applied depth.

The water use efficiency correlates biomass production or commercial production with the amount of applied or evapotranspired water (HOWELL, 2001; MANTOVANI et al., 2013; VIEIRA et al., 2015, 2018). This information is important for the economic analysis of productive systems, as well as contributing to the economics of water use (SANDRI; MATSURA; TESTEZLAF, 2007).

The highest water use efficiency, according to the model, was obtained with the applied depth of $919.68 \mathrm{~mm}(\mathrm{P}<0.001)$ (Figure $4 \mathrm{c})$. Reduction of the applied water depth resulted in an increase in water use efficiency, reaching a maximum value of $14.21 \mathrm{~kg} \mathrm{~m}^{-3}$. Similar to this study, Pereira, Moreira and Klar (2002), studying the effect of soil cover levels on irrigation management of common bean, also observed greater water use efficiency with treatments involving smaller applied depths. In contrast, Mantovani et al. (2013), in an investigation of water use efficiency with two sweet potato cultivars in response to different irrigation depths, found that an increase in the applied water depth resulted in an increase in the water use efficiency; this reached a maximum value of $16.1 \mathrm{~kg} \mathrm{~m}^{-3}$ with application of $301.8 \mathrm{~mm}$ with the 'Amanda' cultivar and $20.0 \mathrm{~kg} \mathrm{~m}^{-3}$, with application of $332.4 \mathrm{~mm}$ with the 'Duda' cultivar.

The lowest water use efficiency was obtained with the applied depth of 1,564.93 $\mathrm{mm}$, which was $8.15 \mathrm{~kg} \mathrm{~m}^{-3}$. This result was already expected due to the lowest productivity obtained with this treatment (Figure 4d).

With regard to production of total rhizomes the best results were found with a depth of $1,133.33$ $\mathrm{mm}(\mathrm{P}=0.246)$ (Figure $4 \mathrm{~d})$. In the case of the production of export rhizomes, which are considered to have the highest commercial value, these followed the same trend as total rhizomes, as shown in Figure 4 (e). Thus, the total depth that provided the highest yield of export quality rhizomes was $1,178.57 \mathrm{~mm}(\mathrm{P}=0.119)$. Irrigation contributes to vegetative growth, increasing photosynthesis and results in the highest yield of rhizomes per hectare. The irrigation should be continuous and applied in the correct amount throughout the cycle. In an evaluation of the effect of irrigation on ginger growth and yield, Islam, 
Performance of ginger...

Rahim and Iqbal (2015) reported much lower productivity than in the present study, ranging from 14.76 to $25.07 \mathrm{t} \mathrm{ha}^{-1}$, when only two irrigations were carried out during the dry period (seven days before and 60 days after planting).

With regard to the production of small rhizomes (Figure 4f), there was a quadratic tendency, where the smallest number of small rhizomes was associated with the application of a total depth of $1,234.38 \mathrm{~mm}(\mathrm{P}=0.195)$. In this sense, it is worth mentioning that the use of total water depths in the range 1,100 to $1,200 \mathrm{~mm}$ during the growth cycle of ginger plants promotes the production of larger rhizomes and, consequently, has greater economic value.

The largest yields of small rhizomes with the lowest and the highest total applied depths (919.68 and $1564.93 \mathrm{~mm}$, respectively) may be related to an inadequate supply of water, causing imbalance in the physiological processes of the plant. Water deficit can cause reduction in the photosynthetic rate and reduction of cellular expansion, reducing plant growth. In addition, soil water excess can result in nutrient losses due to
MENEGHELLI, C. et al.

leaching and, consequently, nutrient deficiency in the plant, plus soil hypoxia (MELO et al., 2010).

In general, even if the water use efficiency is higher with the smallest total applied depth, it does not result in the highest productivity. Thus, it is recommended that total depths of around 1,100 to $1,200 \mathrm{~mm}$ per cycle are used, since the water use efficiency and productivity in this range are higher compared to depths above $1,200 \mathrm{~mm}$ per cycle. In addition, in this range $(1,100$ to $1,200 \mathrm{~mm}$ per cycle), the highest yields of total and export quality rhizomes occurred, highest mean mass of export quality rhizomes and lowest production of small rhizomes.

\section{CONCLUSION}

Total water depths applied in the range 1,100 to $1,200 \mathrm{~mm}$ per cycle, i.e. 75 to $100 \%$ of the ETc. favor the development of ginger plants, producing the highest yields of total and export rhizomes, the highest average mass of export quality rhizome and the lowest production of small rhizomes.

RESUMO: Para que se alcance bons rendimentos e lucratividade com a cultura do gengibre o fornecimento de água deve ser adequado. Entretanto, ainda são poucos os trabalhos que avaliam o adequado fornecimento de água para esta hortaliça. Frente a isso, objetivou-se avaliar o efeito de diferentes lâminas de irrigação no desenvolvimento e na produtividade da cultura do gengibre. A pesquisa foi conduzida na propriedade "Sítio Schmidt" localizada no município de Santa Maria de Jetibá, região Central Serrana do Estado do Espírito Santo. O delineamento experimental utilizado foi o de blocos casualizados, com quatro repetições, sendo cada unidade experimental constituída por três fileiras em um espaçamento de $0,90 \mathrm{~m}$ e 0,10 $\mathrm{m}$ entre plantas de dois metros de extensão, totalizando 20 unidades experimentais. Os tratamentos consistiram na aplicação de cinco lâminas de irrigação, sendo elas: 50\%, 75\%, 100\%, 125\% e 150\%. Foram avaliados o número de brotações; a massa média dos rizomas com padrão tipo exportação; as produtividades de rizomas tipo exportação, pequeno e total $\left(\mathrm{t} \mathrm{ha}^{-1}\right)$; e a eficiência do uso da água. A lâmina total aplicada na faixa de 1100$1200 \mathrm{~mm}$ por ciclo, ou seja, 75 a $100 \%$ da ETc favorece o desenvolvimento de plantas de gengibre, proporcionando maiores produtividades de rizoma total e tipo exportação, maior massa média de rizoma tipo exportação e menor produção de rizomas pequenos.

PALAVRAS-CHAVE: Uso da Água. Eficiência. Evapotranspiração. Horticultura. Estresse Hídrico.

\section{REFERENCES}

ALLEN, R. G.; PEREIRA, L. S.; RAES, D.; SMITH, M. Crop evapotranspiration - Guidelines for computing crop water requirements. Irrigation and Drainage paper 56. Rome: FAO, 1998. 319 p.

CARMO, C. A. S.; BALBINO, J. M. S. Gengibre. Vitória, ES: Incaper, 2015. 192 p.

COSTA, C. P. M.; GUERRA, H. O. C.; ZONTA, J. H.; CARVALHO, C. M.; SOUSA, P. G. R.; CARVALHO, L. L. S. Crescimento inicial da mamoneira 'BRS Gabriela' submetida a níveis de irrigação. Revista Brasileira de Agricultura Irrigada, Fortaleza, v. 11, n. 4, p. 1538-1547, 2017. https://doi.org/10.7127/rbai.v1 1n400593 
DOORENBOS, J.; PRUITT, J. O. Guidelines for predicting crop water requirements. Rome: FAO, 1977. $179 \mathrm{p}$.

DUTRA, C. C.; PRADO, E. A. F.; PAIM, L. R.; SCALON, S. P. Q. Desenvolvimento de plantas de girassol sob diferentes condições de fornecimento de água. Semina: Ciências Agrárias, Londrina, v. 33, n. 1, p. $2657-$ 2668, 2012. https://doi.org/10.5433/1679-0359.2012v33Supl1p2657

ELPO, E. R. S.; NEGRELLE, R. R. B.; RÜCKER, N. G. A. Produção de gengibre no município de Morretes, PR. Scientia Agraria, Curitiba, v. 9, n. 2, p. 211-217, 2008. https://doi.org/10.5380/rsa.v9i2.10971

ESPÍNDULA JÚNIOR, A.; CUNHA DOS ANJOS, L. H., PEREIRA, M. G.; ZONTA, E.; SCHULTZ, N.; GUARESCHI, R. F. Adubação fosfatada para a cultura do gengibre na região serrana do Espírito

Santo. Revista Caatinga, Mossoró, v. 27, n. 4, p. 126 - 134, 2014.

FERREIRA, D. F. Sisvar: a computerstatisticalanalysis system. Ciência e Agrotecnologia, Lavras, v. 35, n. 6, p. 1039-1042, 2011. https://doi.org/10.1590/S1413-70542011000600001

GAVA, R.; FRIZZONE, J. A.; SNYDER, R. L.; ALMEIDA, B. M.; DE FREITAS, P. S. L.; REZENDE, R. Strategies of deficit water management in irrigation of soybean crop. Revista Brasileira de Engenharia de Biossistemas, Tupã, v. 10, n. 3, p. 305-315, 2016. https://doi.org/10.18011/bioeng2016v10n3p305-315

HOWELL, T. A. Enhancing water use efficiency in irrigated agriculture. Agronomy Journal, v. 93, n. 2, p. 281-289, 2001. https://doi.org/10.2134/agronj2001.932281x

ISLAM, M. A.; RAHIM, M. A.; IQBAL, T. M. T. Effect of Irrigation and Mulching on Growth and Yield of Ginger. Bangladesh Agronomy Journal, Bangladesh, v. 18, n. 1, p. 27-36, 2015.

https://doi.org/10.3329/baj.v18i1.25564

KIZHAKKAYIL, J.; SASIKUMAR, B. Diversity, characterization and utilization of ginger: A review. Plant Genetic Resources, Cambridge, v. 9, n. 3, p. 464-477, 2011. https://doi.org/10.1017/S1479262111000670

KUMAR, M.; DUBEY, S.; DWIVEDI, P. K.; YADAV, A. K.; KUMAR, M. Influence of Different Mulch Materials on Vegetative Growth and Yield of Ginger (Zingiber officinale Rosc.) under Drip Irrigation System. International Journal of Current Microbiology and Applied Sciences, Tamilnadu, v. 7, n. 2, p. 2546-2551, 2018. https://doi.org/10.20546/ijcmas.2018.702.310

MANHÃES, C. M. C.; GARCIA, R. F.; FRANCELINO, F. M. A.; OLIVEIRA FRANCELINO, H.; COELHO, F. C. Fatores que afetam a brotação e o perfilhamento da cana-de-açúcar. Vértices, Campos dos Goytacazes, v. 17, n. 1, p. 163-181, 2015. https://doi.org/10.5935/1809-2667.20150011

MANTOVANI, E. C.; COSTA, L. C. Manual do SISDA 2.0 - Workshop Internacional sobre Manejo Integrado das Culturas e Recursos Hídricos. Viçosa, 1998. 153 p.

MANTOVANI, E. C.; BERNARdO, S.; PALARETTI, L. F. Irrigação - Princípios e Métodos. 3. ed. Viçosa: Editora UFV, 2009. 355 p.

MANTOVANI, E. C.; DELAZARI, F. T.; DIAS, L. E.; DE ASSIS, I. R.; VIEIRA, G. H. S.; LANDIM, F. M. Eficiência no uso da água de duas cultivares de batata-doce em resposta a diferentes lâminas de irrigação. Horticultura Brasileira, Brasília, v. 31, n. 4, p. 602-606, 2013. https://doi.org/10.1590/S010205362013000400015

MELO, S. A.; SUASSUNA, J. S.; FERNANDES, P. D.; BRITO, M. E. B.; SUASSUNA, A. F.; NETTO, A. O. A. Crescimento vegetativo, resistência estomática, eficiência fotossintética e rendimento do fruto da melancieira em diferentes níveis de água. Acta Scientiarum Agronomy, Maringá, v. 32, n. 1, p. 73-79, 2010. https://doi.org/10.4025/actasciagron.v32i1.2136 
PACHECO, A.; LOPES, A. S.; OLIVEIRA, G. Q.; FRANÇA, A.; SILVA, L. E. Diferentes métodos de manejo de irrigação e doses de adubação nitrogenada nos componentes de produtividade e eficiência no uso da água.

Revista Agrarian, Dourados, v. 9, n. 33, p. 263-273, 2016.

PEREIRA, A. L.; MOREIRA, J. A. A.; KLAR, A. E. Efeito de níveis de cobertura do solo sobre o manejo da irrigação do feijoeiro (Phaseolus vulgaris L.). Irriga, Botucatu, v. 7, n. 1, p. 42-52, 2002.

https://doi.org/10.15809/irriga.2002v7n1p42

PREZOTTI, L. C.; GOMES, J. A.; DADALTO, G. G.; OLIVEIRA, J. A. Manual de recomendação de calagem e adubação para o Estado do Espírito Santo: $5^{a}$ aproximação. Vitória:

SEEA/INCAPER/CEDAGRO, 2007. 305 p.

RAVINDRAN, P. N.; NIRMALBABU, K.; SHIVA, K. N. Botany and Crop Improvement of Ginger. In: Ginger The Genus Zingiber. 1 ed. Washington: PN. Ravindran; K. NirmalBabu. 2005. p. 15-33.

RODRIGUES, R. R.; PIZETTA, S. C.; SILVA, N. K. C.; RIBEIRO, W. R.; DOS REIS, E. F. Crescimento inicial do cafeeiro conilon sob déficit hídrico no solo. Coffee Science, Lavras, v. 11, n. 1, p. 33-38, 2016.

SANDRI, D.; MATSURA, E. E.; TESTEZLAF, R. Desenvolvimento da alface Elisa em diferentes sistemas de irrigação com água residuária. Engenharia Agrícola e Ambiental, Campina Grande, v. 11, n. 1, p. 17-29, 2007. https://doi.org/10.1590/S1415-43662007000100003

SILVA, F. A. S.; AZEVEDO, C. A. V. The Assistat Software Version 7.7 and its use in the analysis of experimental data. African Journal of Agricultural Research, v. 11, n. 39, p. 3733-3740, 2016. https://doi.org/10.5897/AJAR2016.11522

TAIZ, L.; ZEIGER, E. Fisiologia vegetal. 5. ed. Porto Alegre: Artmed, 2013. 954 p.

VIEIRA, G. H. S.; MANTOVANI, E. C.; SEDIYAMA, G. C.; LO MONACO, P. A. V. Lâminas de irrigação em cana-de-açúcar para diferentes condições de disponibilidade hídrica. Irriga, Botucatu, Ed. Esp. p. 137-148, 2015. https://doi.org/10.15809/irriga.2015v1n2p137

VIEIRA, G. H. S.; PETERLE, G.; LOSS; J. B.; PETERLE, G.; POLONI, C. M. M.; COLOMBO, J. N.; LO MONACO, P. A. V. Strategies for taro (Colocasia esculenta) irrigation. Journal of Experimental Agriculture International, Londres, v. 24, n. 1, p. 1-9, 2018. https://doi.org/10.9734/JEAI/2018/41516

ZAMBRANO-BLANCO, E. Diversidad genética del jengibre (Zingiber officinale Roscoe.) A nivel molecular: Avances de la última década. Entramado, Cali, v. 11, n. 2, p. 190-199, 2015.

https://doi.org/10.18041/entramado.2015v11n2.22239 